\title{
NOTES
}

\section{Lactobacillus paraplantarum sp. nov., a New Species Related to Lactobacillus plantarum}

\author{
MARIE-CHRISTINE CURK, JEAN-CLAUDE HUBERT, AND FRANÇOISE BRINGEL* \\ Laboratoire de Microbiologie et de Génétique, URA Centre National de la Recherche Scientifique D 1481, \\ Institut de Botanique, 67083 Strasbourg Cedex, France
}

\begin{abstract}
Four strains of facultatively heterofermentative lactobacilli isolated from beer and human feces have physiological characteristics similar to those of Lactobacillus plantarum. Unlike $66 \%$ of the L. plantarum strains tested (F. Bringel, M.-C. Curk, and J.-C. Hubert, Int. J. Syst. Bacteriol. 46:588-594, 1996), these strains do not catabolize $\alpha$-methyl-D-mannoside. However, because they exhibit little DNA relatedness to $L$. plantarum and Lactobacillus pentosus, these four strains were classified as members of a new species, Lactobacillus paraplantarum; strain CNRZ 1885 (= CIP 104668) is the type strain.
\end{abstract}

The species Lactobacillus plantarum has been described as a taxon which exhibits phenotypic and genomic heterogeneity. Nucleic acid hybridization studies have clearly demonstrated the differences between $L$. plantarum and Lactobacillus pentosus $(8,18)$, and some strains have been shown to be neither $L$. plantarum nor $L$. pentosus strains (8). The taxonomic positions of these organisms have remained uncertain. When we studied the restriction fragment length polymorphisms of the de novo biosynthetic pyrimidine genes (2), four strains previously identified as $L$. plantarum strains (strains CNRZ $1885^{\mathrm{T}}[\mathrm{T}=$ type strain], CNRZ 1887, 61D, and ATCC 10776) produced peculiar restriction profiles. The $L$. plantanum strains produced three bands (at 7, 4, and $1 \mathrm{~kb}$ ), whereas the L. pentosus strains produced only one band (at about $7 \mathrm{~kb}$ ) and strains CNRZ $1885^{\mathrm{T}}$, CNRZ $1887,61 \mathrm{D}$, and ATCC 10776 produced two bands (at 4 and $1 \mathrm{~kb}$ ). In this study, we found that the latter four strains appear to belong to a new species which differs from $L$. plantarum and $L$. pentosus. Below we propose the name Lactobacillus paraplantarum for this new species and present a description of it.

All strains (Table 1) were grown on MRS agar (9) at $30^{\circ} \mathrm{C}$ in a $4 \% \mathrm{CO}_{2}$-enriched atmosphere for $48 \mathrm{~h}$ and were stored at $4^{\circ} \mathrm{C}$. For physiological tests, MRS broth $(8 \mathrm{ml})$ was inoculated with lactobacilli from MRS agar plates, and the resulting culture was grown at $30^{\circ} \mathrm{C}$ in a $4 \% \mathrm{CO}_{2}$-enriched atmosphere for $24 \mathrm{~h}$. This culture was subsequently used to inoculate MRS broth cultures incubated at $15,30,37$, and $45^{\circ} \mathrm{C}$ when the growth temperature was tested, in a $4 \% \mathrm{CO}_{2}$-enriched atmosphere or under aerobic conditions when the effect of oxygen on growth was studied. To estimate the effect of $\mathrm{NaCl}$ on growth, cells were grown at $30^{\circ} \mathrm{C}$ in a $4 \% \mathrm{CO}_{2}$-enriched atmosphere in MRS broth preparations supplemented with $4,6,8$, and $10 \%(\mathrm{wt} / \mathrm{vol}) \mathrm{NaCl}$. The effect of $\mathrm{pH}$ on growth was determined in MRS adjusted to pHs 4 and 5 with acetic acid and to $\mathrm{pH} 7$ with $\mathrm{NaOH}$. The production of gas from glucose was determined with MRS broth lacking beef extract, and the production of gas from gluconate was determined with MRS lack-

\footnotetext{
* Corresponding author. Mailing address: Laboratoire de Microbiologie et de Génétique, URA CNRS D 1481, Institut de Botanique, 28 rue Goethe, 67083 Strasbourg Cedex, France. Electronic mail address: bringel@gem.u-strabg.fr.
}

ing beef extract and glucose but containing gluconate $(10 \mathrm{~g}$ liter ${ }^{-1}$ ). The gas that was produced was trapped in Durham tubes. To study arginine degradation by the arginine deiminase pathway, cultures of strains on MRS agar were subcultured in MRS broth for $24 \mathrm{~h}$ and then in two tubes containing $5 \mathrm{ml}$ of Niven medium $\left(2 \mathrm{~g}\right.$ of $\mathrm{K}_{2} \mathrm{HPO}_{4}$ per liter, $3 \mathrm{~g}$ of L-arginine per liter, $0.1 \%$ [vol/vol] Tween $80,50 \mathrm{mg}$ of $\mathrm{MnSO}_{4}$ per liter; $\mathrm{pH}$ adjusted to 7 ); glucose at a final concentration of $2 \%(\mathrm{wt} / \mathrm{vol})$ was added to one tube, and glucose at a final concentration of $0.05 \%(\mathrm{wt} / \mathrm{vol})$ was added to the other tube (7). The cultures

TABLE 1. Strains studied ${ }^{\prime}$

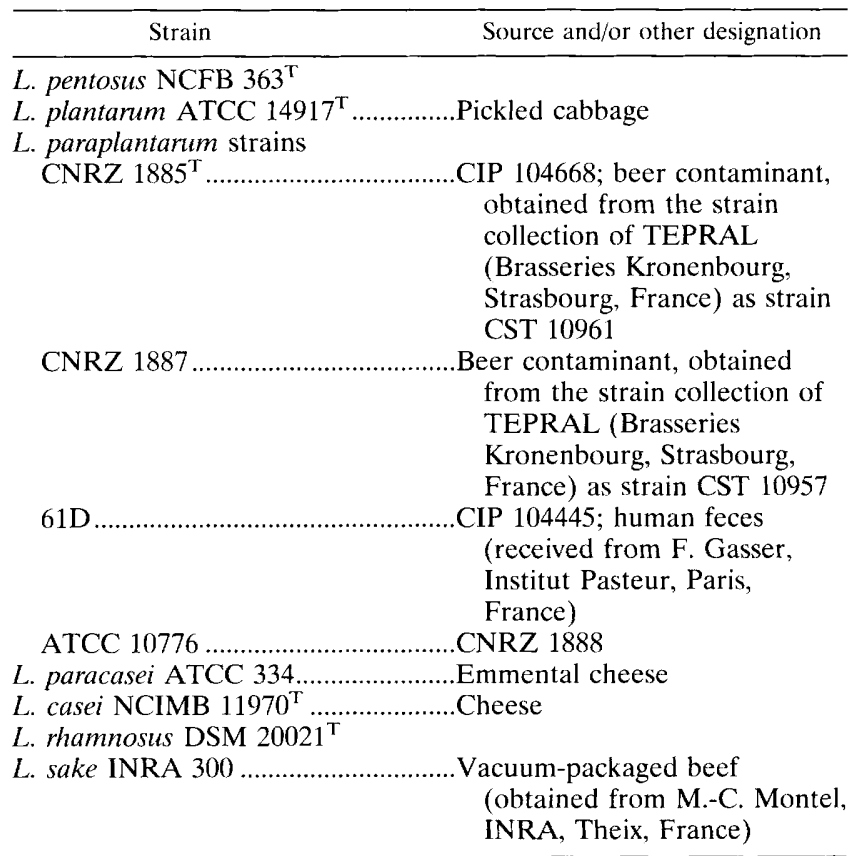

"ATCC, American Type Culture Collection, Rockville, Md.; CNRZ, Centre National de Recherches Zootechniques, Jouy-en-Josas, France; DSM, Deutsche Sammlung von Mikroorganisn.en, Branschweig, Germany; NCFB, National Collection of Food Bacteria, Reading, United Kingdom; NCIMB, National Collection of Industrial and Marine Bacteria, Aberdeen, Scotland, United Kingdom; INRA, Institut National de la Recherche Agronomique. 
TABLE 2. DNA base compositions, thermal stabilities, and levels of DNA hybridization for L. paraplantarum strains and other Lactobacillus strains

\begin{tabular}{|c|c|c|c|c|c|c|c|c|}
\hline \multirow{2}{*}{ Strain } & \multirow{2}{*}{$\begin{array}{l}\mathrm{G}+\mathrm{C} \text { content } \\
\quad(\mathrm{mol} \%)\end{array}$} & \multirow{2}{*}{$\begin{array}{c}\text { Thermal stability } \\
\left({ }^{\circ} \mathrm{C}\right) \text { of duplexes } \\
\text { formed with } \\
{ }^{3} \mathrm{H}-\text {-labeled CNRZ } \\
1885^{\mathrm{T}} \text { DNA }\end{array}$} & \multicolumn{6}{|c|}{$\%$ Relative binding with $\left[{ }^{3} \mathrm{H}\right] \mathrm{DNA}$ from: } \\
\hline & & & $\begin{array}{l}\text { L. paraplantarum } \\
\text { CNRZ } 1885^{\mathrm{T}}\end{array}$ & $\begin{array}{l}\text { L. pentosus } \\
\text { NCFB } 363^{\mathrm{T}}\end{array}$ & $\begin{array}{l}\text { L. plantarum } \\
\text { ATCC } 14917^{\mathrm{T}}\end{array}$ & $\begin{array}{l}\text { L. paracasei } \\
\text { ATCC } 334\end{array}$ & $\begin{array}{c}\text { L. casei } \\
\text { NCIMB } 11970^{\mathrm{T}}\end{array}$ & $\begin{array}{l}\text { L. rhamnosus } \\
\text { DSM } 20021^{\mathrm{T}}\end{array}$ \\
\hline $\begin{array}{l}\text { L. paraplantarum } \\
\text { CNRZ } 1885^{\mathrm{T}}\end{array}$ & 44 & 0 & 100 & 14 & 42 & 0 & 9 & 3 \\
\hline $\begin{array}{l}\text { L. paraplantarum } \\
\text { CNRZ } 1887\end{array}$ & 44 & & 100 & 15 & 43 & 0 & 9 & 3 \\
\hline $\begin{array}{l}\text { L. paraplantarum } \\
61 \mathrm{D}\end{array}$ & 44 & 0.6 & 72 & 20 & 41 & & & \\
\hline $\begin{array}{l}\text { L. paraplantarum } \\
\text { ATCC } 10776\end{array}$ & 45 & & 100 & 23 & 56 & & & \\
\hline $\begin{array}{l}\text { L. plantarum } \\
\text { ATCC } 14917^{\mathrm{T}}\end{array}$ & 41 & 7 & 29 & 15 & 100 & & & \\
\hline $\begin{array}{l}\text { L. pentosus } \\
\text { NCFB } 363^{\mathrm{T}}\end{array}$ & 42 & 13 & 26 & 100 & 20 & & & \\
\hline
\end{tabular}

were centrifuged, and $1 \mathrm{ml}$ of distilled water, $1 \mathrm{ml}$ of $\mathrm{H}_{2} \mathrm{SO}_{4}$ $\mathrm{H}_{3} \mathrm{PO}_{4}(1: 3)$, and $0.13 \mathrm{ml}$ of $3 \%$ (wt/vol) diacetylmonoxime were added to $1 \mathrm{ml}$ of the culture supernatant. An orange color appeared after the preparations were boiled for $10 \mathrm{~min}$, and this allowed us to detect the arginine degradation product, citrulline. Lactobacillus sake INRA 300 was used as the positive control. Strains were tested for their sugar fermentation abilities by using the API 50 CHL system (bioMerieux). The inocula were taken directly from MRS agar. The test preparations were incubated at $30^{\circ} \mathrm{C}$, and readings were obtained after 24,48 , and $72 \mathrm{~h}$. For the peptidoglycan analysis we used cells obtained from MRS agar that were cultivated in $40 \mathrm{ml}$ of MRS broth for $24 \mathrm{~h}$ at $30^{\circ} \mathrm{C}$ in a $\mathrm{CO}_{2}$-enriched atmosphere. The method used to prepare and hydrolyze cell walls was the rapid screening method described by Schleifer and Kandler (16). The cell walls were partially hydrolyzed with $4 \mathrm{M} \mathrm{HCl}$ for $2 \mathrm{~h}$ and analyzed by thin-layer chromatography (15). The hydrolysates were spotted onto a Silica Gel G layer $(20$ by $20 \mathrm{~cm}$; Polygram SIL G/UV 254 ; Macherey-Nagel) and separated by using a $\mathrm{CHCl}_{3}-$ methanol-17\% $\mathrm{NH}_{3}(2: 2: 1$, vol/vol/vol $)$ solvent system for 5 to $6 \mathrm{~h}$. Spots were made visible with ninhydrin (15). To assay the isomers of lactic acid, cells were subcultured in $8 \mathrm{ml}$ of MRS broth under the conditions described above. A $0.1-\mathrm{ml}$ portion of growth medium supernatant was assayed to determine its $\mathrm{D}-(-)$ - and $\mathrm{L}-(+)$-lactic acid contents by using $\mathrm{D}-(-)$-lactate dehydrogenase from Lactobacillus leichmannii
(Boehringer Mannheim) and L-(+)-lactate dehydrogenase from rabbit muscle (Boehringer Mannheim). A 0.1-ml portion of the cell-free supernatant was mixed with a solution containing $0.3 \mathrm{ml}$ of $0.5 \mathrm{M}$ hydrazine- $0.6 \mathrm{M}$ glycine buffer $(\mathrm{pH} 9.2), 0.6$ $\mathrm{ml}$ of distilled water, $1.5 \mathrm{mg}$ of NAD, and $7.5 \mu \mathrm{l}$ of $\mathrm{L}-(+)-$ or $\mathrm{D}-(-)$-lactate dehydrogenase. After incubation for $15 \mathrm{~min}$ at $37^{\circ} \mathrm{C}$, the $A_{340}$ was determined with a Uvikon 930 spectrophotometer (Kontron Instruments). In the control, the supernatant was replaced with distilled water. DNA was extracted by the method of Brenner et al. (1), as modified by Champomier et al. (4). Our determination of the $\mathrm{G}+\mathrm{C}$ content of the DNA (14) was based on the fact that the absorbance of DNA is similar to the absorbance of nucleotides at pH 3. Therefore, the ratio of the molar extinction coefficient at $260 \mathrm{~nm}$ to the molar extinction coefficient at $280 \mathrm{~nm}$ of a DNA solution determined in $0.1 \mathrm{M}$ acetic acid $(\mathrm{pH} 3)$ is a function of the $\mathrm{G}+\mathrm{C}$ content of the DNA. The absorbance profiles of 50 $\mu \mathrm{g} / \mathrm{ml}$ DNA solutions were determined by using a Uvikon 930 spectrophotometer (Kontron Instruments). The DNA used for DNA-DNA hybridization experiments was labeled with $\left[{ }^{3} \mathrm{H}\right] \mathrm{dCTP}\left(30 \mathrm{Ci} \mathrm{mmol}^{-1}\right.$ ) by using a nick translation kit (Amersham) as recommended by the manufacturer. The methods used for dialysis and S1 nuclease hydrolysis of the probe have been described by Grimont et al. (12). Preparations were hybridized at $70^{\circ} \mathrm{C}$ in $0.42 \mathrm{M} \mathrm{NaCl}$ for $16 \mathrm{~h}$. We used the $\mathrm{S} 1$ nuclease-trichloroacetic acid method (6) as modified by Gri-

TABLE 3. Physiological and biochemical characteristics of $L$. paraplantarum strains and L. plantarum and L. pentosus type strains ${ }^{a}$

\begin{tabular}{|c|c|c|c|c|c|c|c|c|c|c|c|c|c|c|c|c|}
\hline \multirow{2}{*}{ Strain } & \multicolumn{4}{|c|}{$\begin{array}{l}\text { Growth in MRS medium } \\
\text { containing: }\end{array}$} & \multicolumn{7}{|c|}{ Growth at: } & \multirow{2}{*}{ 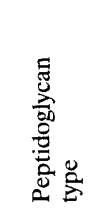 } & \multirow[b]{2}{*}{ 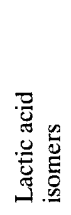 } & \multirow{2}{*}{ 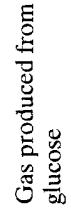 } & \multirow{2}{*}{ 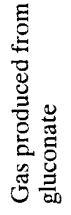 } & \multirow{2}{*}{ 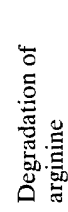 } \\
\hline & $\begin{array}{l}u \\
\tilde{z} \\
\text { go } \\
\text { go }\end{array}$ & $\begin{array}{l}\text { z } \\
z \\
8 \\
0 \\
0\end{array}$ & \begin{tabular}{l}
0 \\
\multirow{2}{*}{} \\
$\infty$ \\
$\infty$
\end{tabular} & $\begin{array}{l}z^{\prime} \\
8 \\
8\end{array}$ & $\underset{I}{J}$ & $\frac{n}{\frac{\pi}{2}}$ & $\underline{T}$ & in & : & : & 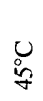 & & & & & \\
\hline ATCC $14917^{\mathrm{T}}$ & + & + & + & - & - & + & + & + & + & + & - & mDAP & $\mathrm{D}, \mathrm{L}$ & - & + & - \\
\hline NCFB $363^{T}$ & + & + & + & - & - & + & + & + & + & + & - & mDAP & $\mathrm{D}, \mathrm{L}$ & - & + & $\begin{array}{cc}- \\
-\end{array}$ \\
\hline CNRZ $1885^{\mathrm{T}}$ & + & + & + & - & - & + & + & + & + & + & - & mDAP & $\mathrm{D}, \mathrm{L}$ & - & + & - \\
\hline CNRZ 1887 & + & + & + & - & - & + & + & + & + & + & - & mDAP & $\mathrm{D}, \mathrm{L}$ & -- & + & - \\
\hline $61 \mathrm{D}$ & + & + & + & - & - & + & + & + & + & + & - & mDAP & $\mathrm{D}, \mathrm{L}$ & - & + & - \\
\hline ATCC 10776 & + & + & + & - & - & + & + & + & + & + & - & mDAP & $\mathrm{D}, \mathrm{L}$ & - & + & - \\
\hline
\end{tabular}

${ }^{a}+$, positive reaction or growth; - , negative reaction or no growth; mDAP, meso-diaminopimelic acid; D, D- $(-)$-lactic acid; L, L- $(+)$-lactic acid. Strains CNRZ $1885^{\mathrm{T}}$ and CNRZ 1887 grew poorly when gluconate was the sole source of carbohydrate. Strains ATCC $14917^{\mathrm{T}}$, NCFB $363^{\mathrm{T}}$, and $61 \mathrm{D}$ grew faster $(24$ to $48 \mathrm{~h})$ than the other strains $(72 \mathrm{~h})$ in MRS medium containing $8 \% \mathrm{NaCl}$. 
mont et al. (12). When the thermal stability of duplexes was tested, the temperature was raised in $5^{\circ} \mathrm{C}$ increments after hybridization at $70^{\circ} \mathrm{C}$. Each time that the temperature was raised, a $100-\mu l$ sample of reassociated DNA was hydrolyzed with $\mathrm{S} 1$ nuclease $(15 \mu \mathrm{l})$ and then treated as described above in the liquid DNA-DNA hybridization procedure. We then extrapolated the temperature at which $50 \%$ of the doublestranded DNA was denatured $\left(T_{m}\right)$. The $\Delta T_{m}$ was the difference between the $T_{m}$ of the homologous duplex and that of the heterologous duplex.

We found that strains CNRZ $1885^{\mathrm{T}}$, CNRZ 1887, ATCC 10776 , and $61 \mathrm{D}$ had a Southern-type hybridization profile different from that of the $L$. plantarum type strain, strain ATCC 14917 (2). The results of DNA-DNA hybridization experiments performed with these strains are shown in Table 2 . If two strains belong to the same species, the level of relative binding of their DNAs is more than $70 \%$ (17) and the thermal stability of the heteroduplex is less than $5^{\circ} \mathrm{C}(11)$. The four strains which we studied exhibited 41 to $56 \%$ relatedness to the $L$. plantarum type strain and 14 to $23 \%$ relatedness to the $L$. pentosus type strain. Dellaglio et al. (8) have previously observed low levels of DNA hybridization between strain ATCC 10776 and the $L$. plantarum and $L$. pentosus type strains. We chose CNRZ $1885^{\mathrm{T}}$ as the reference strain; strains ATCC $10776,61 \mathrm{D}$, and CNRZ 1887 exhibited 72 to $100 \%$ relatedness to CNRZ $1885^{\mathrm{T}}$ (Table 2). Since strain 61D had the lowest level of relative binding $(72 \%)$, the thermal stability of the heteroduplex was determined, and the value obtained was $0.6^{\circ} \mathrm{C}$; therefore, the four strains which we studied belong to one genotypic taxon. Since some strains of Lactobacillus casei, Lactobacillus rhamnosus, and Lactobacillus paracasei have physiological characteristics similar to those of $L$. plantarum, CNRZ $1885^{\mathrm{T}}$ and CNRZ 1887 were hybridized with these lactobacilli, and the levels of relative binding obtained were less than $9 \%$ (Table 2). Moreover, the thermal stability value of the $L$. plantarum type strain-strain CNRZ $1885^{\mathrm{T}}$ heteroduplex was $7^{\circ} \mathrm{C}$ and the thermal stability value of the $L$. pentosus type strain-strain CNRZ $1885^{\mathrm{T}}$ heteroduplex was $13^{\circ} \mathrm{C}$. These data confirmed that CNRZ $1885^{\mathrm{T}}$ belongs to a distinct species which differs from the closely related species $L$. plantarum and $L$. pentosus. The four strains which we studied also had $\mathrm{G}+\mathrm{C}$ contents of 44 to $45 \mathrm{~mol} \%$; these values were somewhat higher than the values obtained for $L$. plantarum and $L$. pentosus (41 and $42 \mathrm{~mol} \%$, respectively) (Table 2). Other Lactobacillus species have similar $\mathrm{G}+\mathrm{C}$ contents, as follows: Lactobacillus graminis, 41 to 44 mol\%; Lactobacillus murinus, 43 to 44 mol\%; and L. sake and Lactobacillus curvatus, 42 to $44 \mathrm{~mol} \%$. On the basis of the results of a $16 \mathrm{~S}$ rRNA sequence phylogenetic analysis, Collins et al. (5) showed that within the $L$. case $i$ Pediococcus cluster $L$. graminis, $L$. curvatus, and $L$. sake form a clade which does not include $L$. plantarum. A partial $16 \mathrm{~S}$ rRNA sequence of strain ATCC 10776 has been shown to be identical to sequences of $L$. plantarum and $L$. pentosus, confirming that $L$. paraplantarum is distinct from $L$. sake, $L$. curvatus, and $L$. graminis (13). L. paraplantarum is also distinct from $L$. murinus as shown by the results of a restriction fragment length polymorphism analysis of the pyrimidine genes (2) performed with L. murinus type strain CNRZ $220^{\mathrm{T}}$ (data not shown).

We also studied physiological and biochemical characteristics of strains CNRZ $1885^{\mathrm{T}}$, CNRZ $1887,61 \mathrm{D}$, and ATCC 10776 (Table 3). These four strains could not be distinguished from the $L$. pentosus and $L$. plantarum type strains on the basis of the data obtained for most of the physiological and biochemical characteristics studied; none of the strains grew in the presence of $\mathrm{NaCl}$ concentrations greater than $8 \%$, at $\mathrm{pH} 4$, or

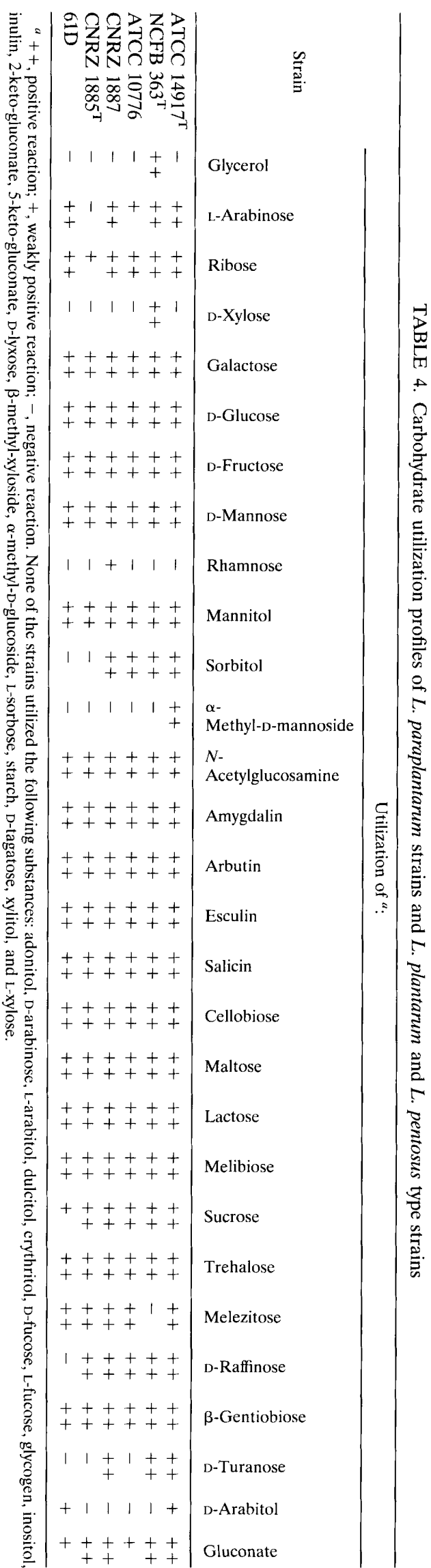


at $45^{\circ} \mathrm{C}$, all strains had meso-diaminopimelic acid in the peptidoglycan and produced DL-lactic acid, and none of the strains deaminated arginine (Table 3). All of the strains were facultatively heterofermentative. Thus, the four strains which we studied could not be distinguished from $L$. plantarum or $L$. pentosus by these physiological characteristics but could be distinguished from the other streptobacterial species. Gasser (10) showed that the lactic acid dehydrogenase zymogram of strain $61 \mathrm{D}$ differed from the lactic acid dehydrogenase zymograms of $L$. plantarum strains. Strain $61 D$ has one-NAD-dependent L- $(-)$-lactic acid dehydrogenase and one NAD-independent $\mathrm{D}-(+)$-lactic acid dehydrogenase, while $L$. plantarum has two NAD-dependent $\mathrm{L}-(-)$ - and $\mathrm{D}-(+)$-lactic acid dehydrogenases. Strain 61D contains many plasmids, and one of them is similar to plasmid pLP1 isolated from $L$. plantarum CCM 1904 (3). Sugar fermentation profiles (Table 4) revealed that the four strains which we studied and L. plantarum can be differentiated from the type strain of $L$. pentosus and most of the strains of this species (2) by glycerol and D-xylose fermentation and not by melezitose fermentation. The four strains which we studied (Table 4) could be distinguished from $L$. plantarum by the fact that $66 \%$ of the L. plantarum strains but none of the four strains which we studied were able to use $\alpha$-methyl-D-mannoside, as shown by Bringel et al. (2).

$L$. plantarum, $L$. pentosus, and the four strains which we studied are difficult to distinguish on the basis of phenotypic characteristics. On the other hand, strains CNRZ $1885^{\mathrm{T}}$, CNRZ 1887, 61D, and ATCC 10776 can be clearly differentiated from $L$. plantanum and $L$. pentosus by using DNA similarity values. We decided to name the new species $L$. paraplantarum because of its phenotypic similarity to L. plantarum. A description of $L$. paraplantarum is given below.

Description of Lactobacillus paraplantarum sp. nov. Lactobacillus paraplantarum (pa. ra. plan. tar' um. Gr. prep. para, resembling; L. gen. n. plantarum, specific epithet of $L$. plantarum; M. L. adj. paraplantarum, resembling L. plantarum). Cells are rod shaped and occur singly, in pairs, and sometimes in short chains. Colonies grown on MRS agar are round, smooth, dome shaped, and creamy colored. Cells are nonmotile, Gram positive, catalase negative, and facultatively anaerobic. Grows at 15 (slowly), 30 , and $37^{\circ} \mathrm{C}$, but not at $45^{\circ} \mathrm{C}$. Grows in MRS medium at pHs 5 and 7, but not at $\mathrm{pH} \mathrm{4}$. Grows in MRS medium containing $\mathrm{NaCl}$ up to a concentration of $8 \%$. Facultatively heterofermentative, producing $\mathrm{D}-(-)$ - and $\mathrm{L}-(+)$-lactic acids. All strains ferment ribose, galactose, D-glucose, D-fructose, D-mannose, mannitol, $N$-acetylglucosamine, amygdalin, arbutin, salicin, cellobiose, maltose, lactose, melibiose, sucrose, trehalose, melezitose, $\beta$-gentiobiose, and gluconate. All strains do not ferment glycerol, erythritol, D-arabinose, D-xylose, Lxylose, adonitol, $\beta$-methyl-xyloside, $L$-sorbose, dulcitol, inositol, $\alpha$-methyl-D-mannoside, $\alpha$-methyl-D-glucoside, inulin, starch, glycogen, xylitol, D-lyxose, D-tagatose, D-fucose, L-fucose, L-arabitol, 2-keto-gluconate, and 5-keto-gluconate. Some strains ferment L-arabinose, L- $(+)$-rhamnose, sorbitol, D-raffinose, D-turanose, and D-arabitol. Esculin is hydrolyzed. Arginine is not deaminated. The peptidoglycan is characterized by the presence of meso-diaminopimelic acid. The $\mathrm{G}+\mathrm{C}$ content of the DNA ranges from 44 to 45 mol\%. Strains have been isolated from beer and human feces in France. The type strain is CNRZ 1885. In most respects, the description of the type strain resembles that of the species. The type strain was isolated from beer, ferments D-raffinose, and does not ferment L-arabinose, sorbitol, D-turanose, and D-arabitol. Its DNA $\mathrm{G}+\mathrm{C}$ content is $44 \mathrm{~mol} \%$.

We thank F. Gasser and M.-C. Montel for sending strains and M. Simon for technical assistance. We also thank P. Taillez for communicating data prior to publication.

\section{REFERENCES}

1. Brenner, D. J., A. C. McWorther, J. K. Leete Knutson, and A. G. Steigerwalt. 1982. Escherichia vulneris: a new species of Enterobacteriaceae associated with human wounds. J. Clin. Microbiol. 15:1133-1140.

2. Bringel, F., M.-C. Curk, and J.-C. Hubert. 1996. Characterization of lactobacilli by Southern-type hybridization with a Lactobacillus plantarum pyrDFE probe. Int. J. Syst. Bacteriol. 46:588-594.

3. Bringel, F., L. Frey, and J.-C. Hubert. 1989. Characterization, cloning, curing and distribution in lactic acid bacteria of pLP1, a plasmid from Lactobacillus plantarum CCM 1904 and its use in shuttle vector construction. Plasmid 22:193-202.

4. Champomier, M.-C., M.-C. Montel, and R. Talon. 1989. Nucleic acid relatedness studies on the genus Camobacterium and related taxa. J. Gen. Microbiol. 135:1391-1394.

5. Collins, M. D., U. Rodrigues, C. Ash, M. Aguirre, J. A. E. Farrow, A. Martinez-Murcia, B. A. Phillips, A. M. Williams, and S. Wallbanks. 1991. Phylogenetic analysis of the genus Lactobacillus and related lactic acid bacteria as determined by reverse transcriptase sequencing of $16 \mathrm{~S}$ rRNA. FEMS Microbiol. Lett. 77:5-12.

6. Crosa, J. H., D. J. Brenner, and S. Falkow. 1973. Use of single-strandspecific nuclease for analysis of bacterial and plasmid deoxyribonucleic acid homo- and heteroduplexes. J. Bacteriol. 115:904-911

7. Curk, M.-C., J.-M. Boeufgras, B. Decaris, F. Gavini, K. Kersters, J. P. Larpent, P. Le Bourgeois, P. Renault, H. de Roissart, and C. Rouvier, 1994. Méthodes d'identification des bactéries lactiques, vol. 1, p. 141-168. In H. de Roissart and F. M. Luquet (coordinators), Bactéries lactiques. Lorica ed., Uriage, France.

8. Dellaglio, F., V. Bottazzi, and M. Vescovo. 1975. Deoxyribonucleic acid homology among Lactobacillus species of the subgenus Streptobacterium Orla-Jensen. Int. J. Syst. Bacteriol. 25:160-172.

9. DeMan, J. C., M. Rogosa, and M. E. Sharpe. 1960. A medium for the cultivation of lactobacilli. J. Appl. Bacteriol. 23:130-135.

10. Gasser, F. 1970. Electrophoretic characterization of lactic dehydrogenases in the genus Lactobacillus. J. Gen. Microbiol. 62:223-239.

11. Grimont, P. A. D. 1984. DNA/DNA hybridization in bacterial taxonomy, p. 11-19. In A. Sanna and G. Morace (ed.), New horizons in microbiology. Elsevier Science Publishers B. V., Amsterdam.

12. Grimont, P. A. D., M. Popoff, F. Grimont, C. Coynault, and M. Lemelin. 1980. Reproducibility and correlation study of three deoxyribonucleic acid hybridization procedures. Curr. Microbiol. 4:325-330.

13. Johansson, M.-L., G. Molin, B. Pettersson, M. Uhlén, and S. Ahrné. 1995. Characterization and species recognition of Lactobacillus plantarim strains by restriction fragment length polymorphism (RFLP) of the 16S rRNA gene. J. Appl. Bacteriol. 79:536-541.

14. Johnson, J. L. 1985. Determination of DNA base composition. Methods Microbiol. 18:1-31.

15. Randerath, K. 1963. Thin-layer chromatography. Verlag Chemie GmbH, Weinheim, Germany.

16. Schleifer, K. H., and O. Kandler. 1972. Peptidoglycan types of bacterial cell walls and their taxonomic implications. Bacteriol. Rev. 36:407-477.

17. Wayne, L. G., D. J. Brenner, R. R. Colwell, P. A. D. Grimont, O. Kandler, M. I. Krichevsky, L. H. Moore, W. E. C. Moore, R. G. E. Murray, E. Stackebrandt, M. P. Starr, and H. G. Trüper. 1987. Report of the Ad Hoc Committee on Reconcilation of Approaches to Bacterial Systematics. Int. J. Syst. Bacteriol. 37:463-464

18. Zanoni, P., J. A. E. Farrow, B. A. Phillips, and M. D. Collins. 1987. Lactobacillus pentosus (Fred, Peterson, and Anderson) sp. nov., nom. rev. Int. J. Syst. Bacteriol, 37:339-341. 